OPEN ACCESS

Edited by:

Aurelio Ciancio,

Istituto per la Protezione Sostenibile

delle Piante, Italy

Reviewed by:

Bala Rathinasabapathi,

University of Florida, USA

Nai-Chun Lin,

National Taiwan University, Taiwan

*Correspondence:

Manish N. Raizada,

Department of Plant Agriculture, University of Guelph, 50 Stone Road East, Guelph, ON N1G 2W1, Canada

raizada@uoguelph.ca

Specialty section:

This article was submitted to Plant Biotic Interactions, a section of the journal Frontiers in Plant Science

Received: 18 June 2015 Accepted: 10 August 2015 Published: 28 August 2015

Citation:

Harding DP and Raizada MN (2015) Controlling weeds with fungi, bacteria

and viruses: a review.

Front. Plant Sci. 6:659.

doi: 10.3389/fpls.2015.00659

\section{Controlling weeds with fungi, bacteria and viruses: a review}

Dylan P. Harding and Manish N. Raizada*

Department of Plant Agriculture, University of Guelph, Guelph, ON, Canada

Weeds are a nuisance in a variety of land uses. The increasing prevalence of both herbicide resistant weeds and bans on cosmetic pesticide use has created a strong impetus to develop novel strategies for controlling weeds. The application of bacteria, fungi and viruses to achieving this goal has received increasingly great attention over the last three decades. Proposed benefits to this strategy include reduced environmental impact, increased target specificity, reduced development costs compared to conventional herbicides and the identification of novel herbicidal mechanisms. This review focuses on examples from North America. Among fungi, the prominent genera to receive attention as bioherbicide candidates include Colletotrichum, Phoma, and Sclerotinia. Among bacteria, Xanthomonas and Pseudomonas share this distinction. The available reports on the application of viruses to controlling weeds are also reviewed. Focus is given to the phytotoxic mechanisms associated with bioherbicide candidates. Achieving consistent suppression of weeds in field conditions is a common challenge to this control strategy, as the efficacy of a bioherbicide candidate is generally more sensitive to environmental variation than a conventional herbicide. Common themes and lessons emerging from the available literature in regard to this challenge are presented. Additionally, future directions for this crop protection strategy are suggested.

Keywords: bioherbicide, herbicide resistance, turf, Colletotrichum, Phoma, Sclerotinia, Xanthomonas, Pseudomonas

\section{Recent History of Weed Control}

Weeds are a problem in both crop production and turfgrass systems, associated with declines in crop yields and quality, as an esthetic nuisance and as a source of allergenic pollen (Stewart-Wade et al., 2002; Oerke, 2006; Gadermaier et al., 2014). Since the post-World War II introduction of the first selective herbicides, 2,4-D and MCPA, such products have significantly changed the management techniques that are employed by farmers and other managers of anthropogenic ecosystems (Mithila et al., 2011). The primary benefit offered by selective herbicides is the ability to control certain weed species without harming crops, based on physiological differences between species. This ability has enabled significant yield increases in many crops, and continues to be an important aspect of agroecosystem management (Mithila et al., 2011). Currently, there are 25 known herbicide target sites at the molecular level (Heap, 2015), e.g., disruption of EPSP synthase required for branched amino acid synthesis by glyphosate (Sammons and Gaines, 2014) or interference of auxin pathways by 2,4-D (Grossmann, 2010). Despite this variety, in many cases a limited number of herbicide mechanisms have been continuously employed by operators based on the low cost or ease of use associated with those products (Beckie, 2011; Mithila et al., 2011). This practice has in many cases created artificial selection pressure on weed populations, causing the widespread emergence of herbicide-resistant weeds (Beckie et al., 1999; Green and Owen, 2011; Mithila et al., 2011; 
Darmency, 2013). As of June, 2015, resistant-weed populations have been reported in association with 22 of the 25 known herbicide targets (Heap, 2015).

The introduction of glyphosate-resistant transgenic crops brought a novel strategy for controlling weeds to the array of options available to operators (Green and Owen, 2011). This approach was notably different from previous selective weed control options in that it enabled the application of a broad spectrum herbicide that controlled almost all plants that were not engineered to tolerate glyphosate (Green and Owen, 2011). The unprecedented efficacy and ease of use associated with this weed control system led to its rapid adoption throughout much of the world, in many cases completely replacing former weed control practices (Beckie, 2011; Green and Owen, 2011). However, as with the generation of selective herbicides before it, the common practice of continuous glyphosate use led to the emergence of resistant weed populations, beginning in 1996 with the observation of glyphosate-resistant rigid ryegrass (Lolium rigidum) in Australia (Green and Owen, 2011). As of the writing of this report, there are 32 glyphosate-resistant weed species throughout the world (Heap, 2015).

It is apparent that as new herbicides are developed, weeds will continue to evolve in response to whatever selective pressure that is applied. For this reason, the continuous development of novel weed control methods is essential to the ongoing maintenance of agricultural yields. These developments are needed both to control weed populations that are resistant to currently available modes of action, as well as to diversify weed control platforms in order to delay the emergence of new resistance traits. Additionally, increasing public concern with the negative effects of pesticide residues, particularly in residential areas (e.g., turfgrass), has led to increasing demand for alternative methods of controlling weeds and other pests (Knopper and Lean, 2004; Bailey et al., 2010; Belair et al., 2010).

\section{Biological Control of Weeds: Introduction and Scope of Review}

Biological control as a general term refers to the introduction of organisms into an ecosystem with the intention of controlling one or more undesirable species (Charudattan, 2001; Bailey et al., 2010). Within the context of controlling weeds and otherwise invasive plant species, this field of study has increasingly focused on bacteria and fungi in the past five decades (Li et al., 2003), although viruses have also been considered for this purpose in select cases (Ferrell et al., 2008; Elliott et al., 2009; Diaz et al., 2014).

There are two primary fields of application within the study of biological weed control. Classical biological control refers to the release of a natural predator or pathogen of a pest species with the anticipation that it will be able to persist in the environment and provide ongoing reduction of the pest species population throughout an entire ecosystem (Dane and Shaw, 1996; TeBeest, 1996; Shaw et al., 2009). On the other hand, inundative biological control (also referred to as the bioherbicide strategy) refers to the application of propagation materials such as fungal spores or bacterial suspensions in concentrations that would not normally occur in nature, with the intention of destroying a pest species within a managed area (Johnson et al., 1996; TeBeest, 1996). The inundative biological control strategy is more relevant to the needs of agriculture and turf management, as it can generally be implemented through the application of inoculum as liquid sprays or solid granules in a similar manner to conventional herbicides (Auld et al., 2003; Caldwell et al., 2012).

In Canada, a significant number of biological agents for control of insects, plant pathogens and weeds has been approved by the Pest Management Regulatory Agency (PMRA), with 24 such products registered between 1972 and 2008, and the majority of these registrations occurring between 2000 and 2008 (Bailey et al., 2010). An even greater number of microbes and microbederived chemicals has been registered with the United States Environmental Protection Agency (EPA) for crop, forest, or ecological management, with 53 such products registered between 1996 and 2010 (EPA, 2014). As of 2014, 47 different microbial strains were approved in the EU for the purpose of controlling fungi or insects (European Parliament, 2014). Surprisingly, there are no microbes approved for the control of weed species in the European Union (European Parliament, 2014).

This review will focus on the use of biological agents to control weeds, including fungi, bacteria and viruses, with examples provided from North America. The review will discuss incentives to adopt these technologies, factors in the real world that affect their efficacy, and challenges to their commercialization. The review will conclude by examining future directions to accelerate progress in this promising field.

\section{Incentives to Adopt Biological Agents to Control Weeds}

The use of bioherbicides in lieu of traditional chemical inputs has the potential to offer a number of benefits to managers of ecological systems, pesticide producers and the general public. Most proponents of biological control strategies cite reduced environmental impact as the primary benefit associated with such management techniques (Auld and Morin, 1995; Johnson et al., 1996; Li et al., 2003; Ghosheh, 2005). This argument has been put forth on the basis of increased target specificity (Auld and Morin, 1995), the rapid degradation of residual biological weed control agent metabolites ( $\mathrm{Li}$ et al., 2003), and the inability of bioherbicide species to propagate without human assistance (Johnson et al., 1996; Hoagland et al., 2007). It has also been argued that the unintended dispersal of introduced biological weed control species can be limited through the employment of agents that cannot survive without their particular host, such as certain strains of Xanthomonas (Schaad et al., 2001). The development cost associated with bioherbicides has also been reported to be generally lower than the cost of developing a comparable chemical agent (Auld and Morin, 1995; Li et al., 2003). Finally, as the public perception of pesticides is generally negative, the development and implementation of lower-risk pest control strategies has the potential to capture the increased willingness of consumers to pay premium prices for foods produced through these methods (Anderson et al., 1996; Bazoche et al., 2014). This has been specifically investigated by McNeil et al. (2010) through a telephone survey of Canadian consumers, in which $70 \%$ of participants indicated preference for foods produced using 
biological control agents rather than synthetic insecticides. It is likely that a similar trend would emerge in regard to consumer preference for biological herbicides over conventional herbicides.

The pressure to develop novel weed control strategies has been additionally increased by the removal of several effective but environmentally problematic pesticides from various markets (Charudattan, 2001). Biological weed control strategies can potentially address this need and provide novel modes of action that will inhibit the growth of weeds that are resistant to more commonly used herbicides. Additionally, it is also possible that in some cases biological control agents could be applied in combination with herbicides to attack weed species through multiple modes of action (Auld and Morin, 1995; TeBeest, 1996).

\section{Biological Control of Weeds Using Fungi}

A list of the biological weed control candidates described in this article is summarized (Table 1). Most commercial biological weed control products researched in North America have been based on formulations of fungal species, however, few have been successful in the long term. Examples include BioMal, a formulation of Colletotrichum gloeosporioides f.sp. malvae, introduced for the control of round leaf mallow (Malva pusilla) (Mortensen, 1988; PMRA, 2006), and C. gloeosporioides f.sp. aeschynomene, which was released for control of northern jointvetch (Aeschynomene virginica) in the United States in 1982 as Collego (Daniel et al., 1973; Menaria, 2007), and again in 2006 as LockDown (EPA Registration Number 82681-1) (Bailey, 2014). Additionally, Sarritor, a formulation of Sclerotinia minor was introduced for the control of dandelion (Taraxacum officinale), white clover (Trifolium repens) and broadleaf plantain (Plantago major) in turf (PMRA, 2010).

Within the scientific literature, three genera of fungi have received the majority of attention as bioherbicide candidates (Table 1). In addition to the aforementioned BioMal and Collego, several other species within the genus Colletotrichum have been investigated. Additional examples include C. truncatum, which has been investigated to control hemp sesbania (Sesbania exaltata) (Schisler et al., 1991), and C. orbiculare, which was investigated for its potential to control spiny cocklebur (Xanthium spinosum) (Auld et al., 1988, 1990). An investigation of the genomes of C. gloeosporioides and C. orbiculare, found that both species contained a number of candidate genes predicted to be associated with pathogenesis, including plant cell wall degrading enzymes and secreted disease effectors including small secreted proteins (SSPs), the latter of which were shown to be differentially expressed in planta according to stage of infection, suggesting that some of these proteins may have specific roles in the infection process (Gan et al., 2013). There is also evidence that both of these Colletotrichum species have the ability to produce indole acetic acid (Gan et al., 2013), a plant hormone, derivatives of which are well established herbicide templates (Grossmann, 2010).

Three species within the genus Phoma have also received attention as potential agents for biological weed control (Table 1). $P$. herbarum, a fungal pathogen originally isolated from dandelion leaf lesions in Southern Ontario, has been investigated for control of dandelions in turf (Neumann and Boland, 1999; Stewart-Wade and Boland, 2005). P. macrostoma has also been investigated for similar purposes as it has been observed to specifically inhibit the growth of dicot plants (Bailey et al., 2011, 2013; Smith et al., 2015). The 94-44B strain of this species has been registered for control of broadleaf weeds in turf systems in Canada and the US (Evans et al., 2013). An investigation of 64 strains of P. macrostoma, including $94-44 \mathrm{~B}$, found that the bioherbicidal activity of these species was limited to a genetically-homogeneous group of strains, all of which were isolated from Canada thistle (Pitt et al., 2012). Through mass spectrometry, P. macrostoma has been recognized to produce photobleaching macrocidins (Graupner et al., 2003) that do not affect monocots (Bailey et al., 2011). As the activity of $P$. macrostoma is most apparent on new growth, it has been suggested that these compounds are transported in the phloem of the host plant (Graupner et al., 2003). Unfortunately, the specific phytotoxic mechanism of macrocidins remains unknown (Schobert and Schlenk, 2008; Zhao et al., 2011; Mo et al., 2014). Despite this, macrocidins and other molecules within the tetramic acid family have received significant attention as templates for the development of novel synthetic herbicides (Barnickel and Schobert, 2010; Yoshinari et al., 2010; Zhao et al., 2011). Additionally, an anthraquinone pigment has been isolated from a $P$. macrostoma strain and shown to have herbicidal effects on several prominent weeds of Central India (Quereshi et al., 2011). Anthraquinone pigments produced by other fungi have also been demonstrated to cause necrosis on wheat leaf blades (Bouras and Strelkov, 2008) and a variety of cultivated legumes (Andolfi et al., 2013). Although the phytotoxic mechanism underlying the effects of these compounds has not been fully characterized, the development of necrosis after exposure to the anthraquinone lentisone was found to be light dependent, a potential clue for the eventual determination of the mechanism associated with this class of molecules (Andolfi et al., 2013). Also of note within this genus is Phoma chenopodicola, which has been investigated as a potential control agent for lamb's quarters (Chenopodium album) (Cimmino et al., 2013). A phytotoxic diterpene, chenopodolin, has been isolated from this species, which was found to cause necrotic lesions on lamb's quarters (Chenopodium album), creeping thistle (Cirsium arvense), green foxtail (Setaria viridis) and annual mercury (Mercurialis annua) (Cimmino et al., 2013). Two additional fungal isolates of the genus Phoma have also been found to cause a modest degree of stem rot on $C$. arvense, however, these isolates were not identified at the species level (Skipp et al., 2013).

Two species within the aforementioned Sclerotinia genus have been investigated for their potential to control weeds. Abu-Dieyeh and Watson (2007a) found that Sclerotinia minor effectively controlled dandelions with and without the presence of turf species in greenhouse conditions. A follow up trial including application of $S$. minor in field conditions confirmed these results (Abu-Dieyeh and Watson, 2007b). As noted earlier, S. minor strain IMI 344141 was introduced to the Canadian lawn care industry under the product name Sarritor in 2010, however, it is no longer commercially available (Watson and Bailey, 2013; see Challenges in Commercialization). A relative of $S$. minor, S. sclerotiorum, has been observed to have phytotoxic activity against creeping 

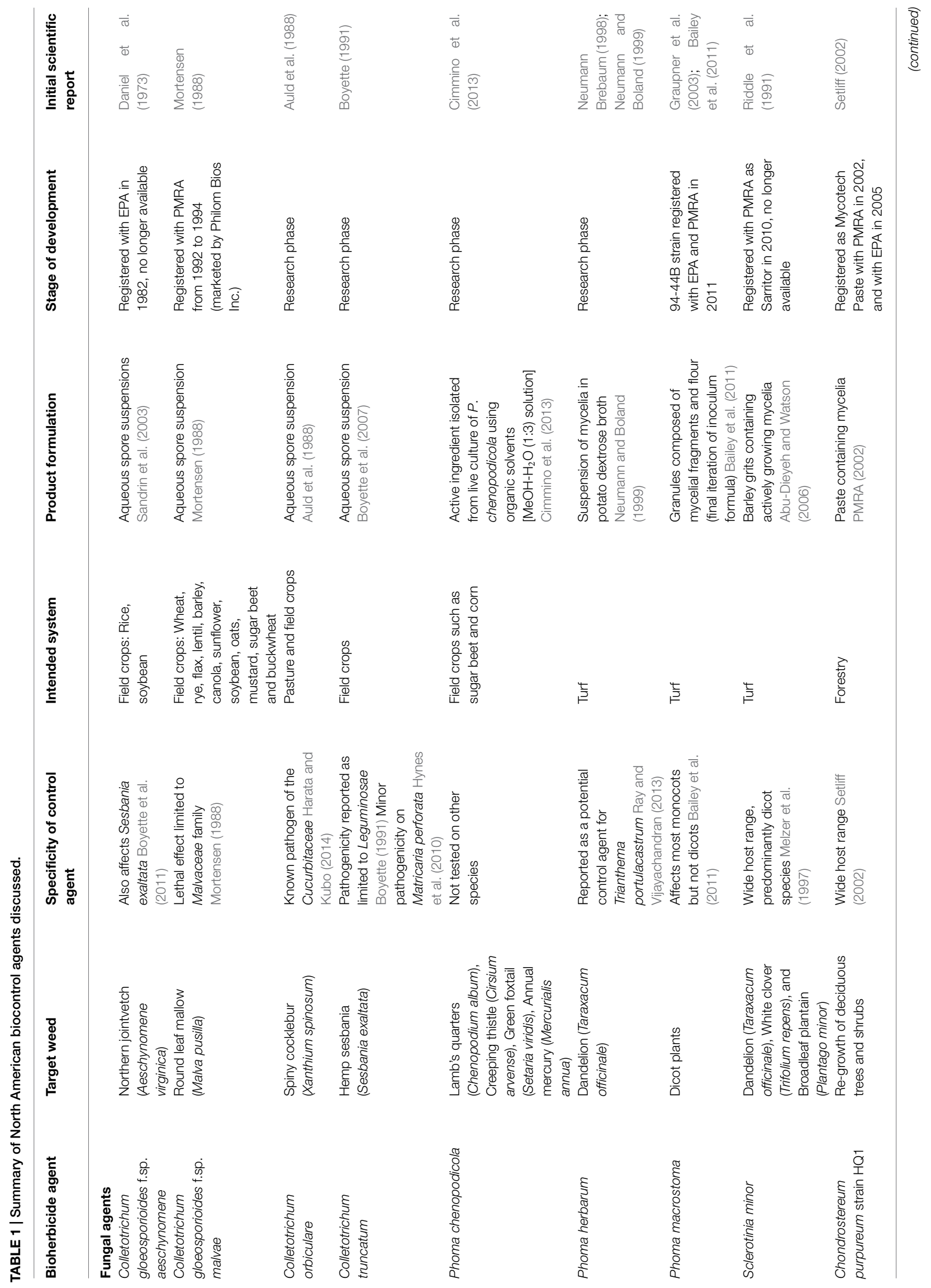


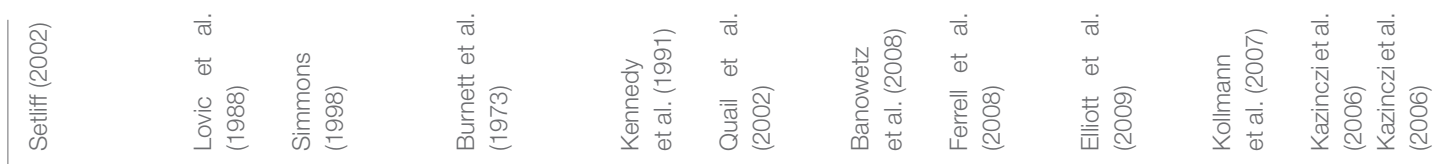

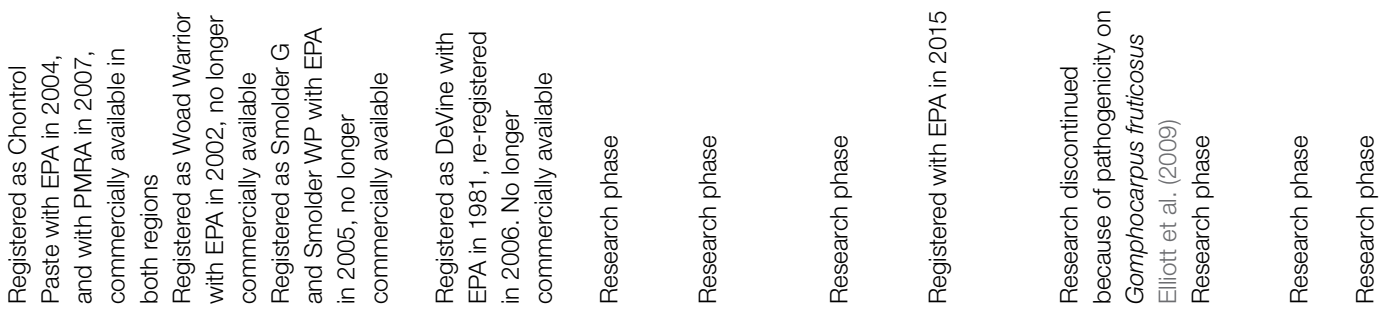

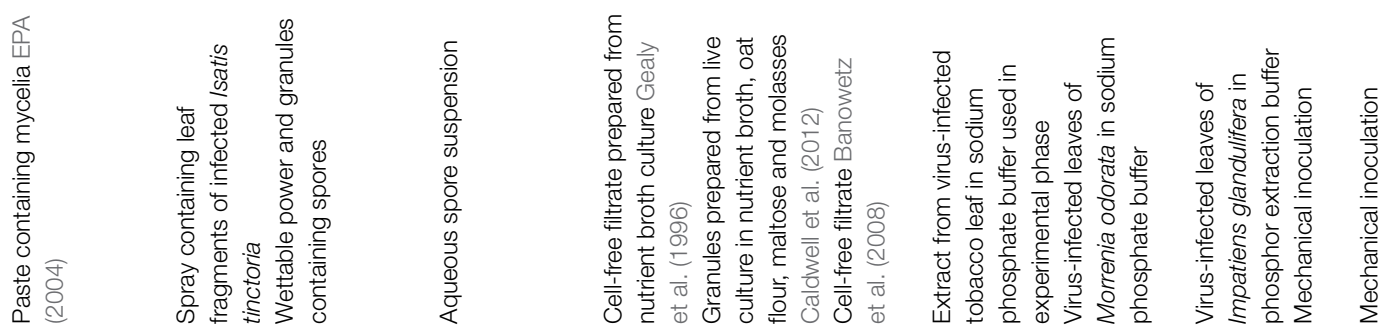

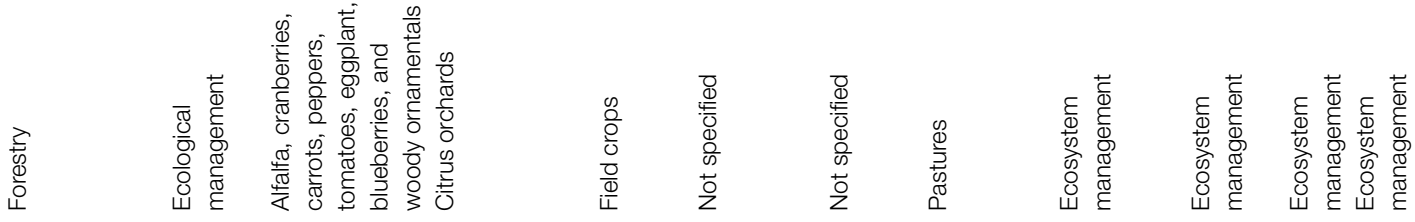

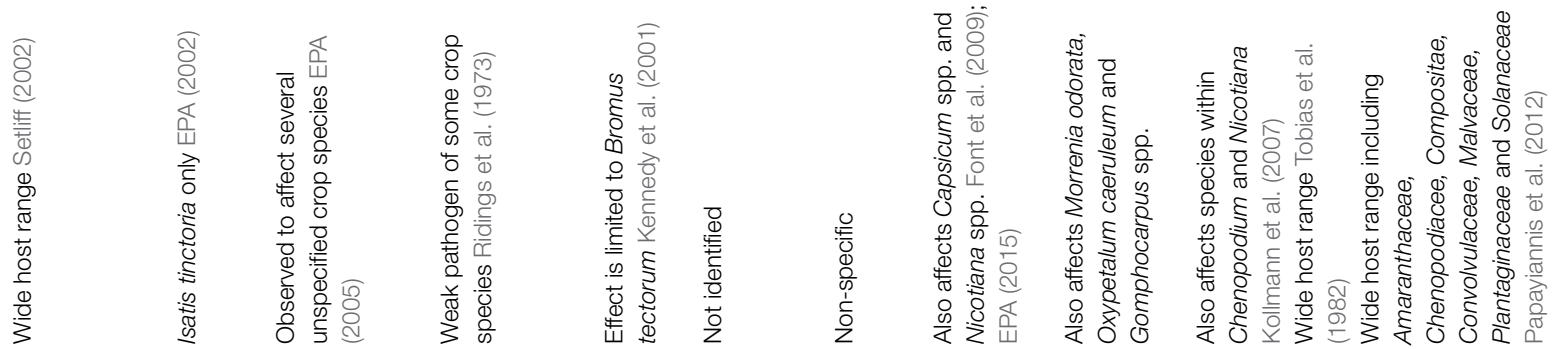

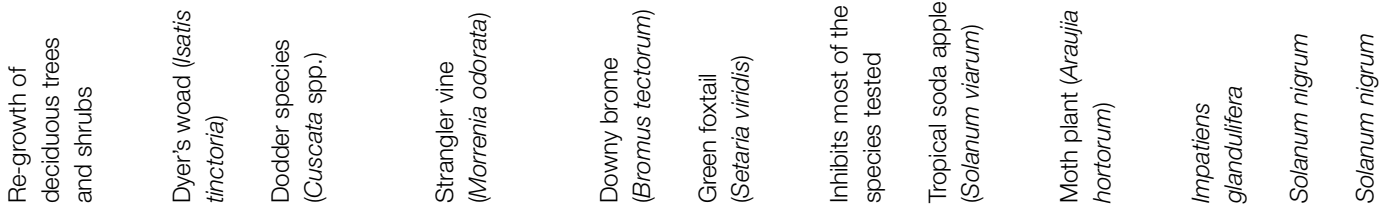

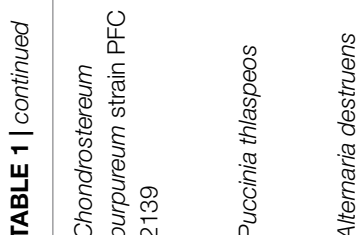

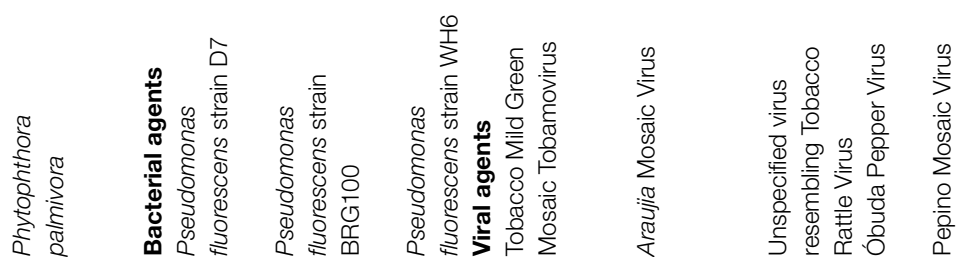


thistle (Cirsium arvense) (Skipp et al., 2013). Production of oxalic acid by both S. minor (Briere et al., 2000) and S. sclerotiorum (Magro et al., 1984) has been observed to play a role in the virulence of these fungi on their host plant. Oxalic acid production can be encouraged through addition of sodium succinate to $S$. minor growth media, and cultures grown on sodium succinateenriched media caused greater development of necrotic tissue when applied to dandelion than cultures grown on non-enriched media (Briere et al., 2000). Oxalic acid acidifies the host tissue, enabling cell wall degradation, and also interferes with polyphenol oxidase (PPO), which normally assists in plant defense (Magro et al., 1984). Low concentrations of oxalic acid have also been shown to suppress the release of hydrogen peroxide, another plant defense molecule, in cell cultures of soy and tobacco (Cessna et al., 2000).

In addition to the other examples described earlier in the text, several other fungi have been registered as bioherbicides for use in forestry or ecosystem management in Canada and the US (Bailey, 2014), though in general, there appears to be limited research about these strains with respect to their mode of action. Two separate strains of Chondrostereum purpureum have been registered in Canada and the US for controlling regrowth of deciduous tree species in coniferous plantations (Bailey, 2014). This fungal species is a naturally occurring pathogen of deciduous trees in North America (Setliff, 2002). Although the potential host range of this species is fairly wide, wound infection is a key element of successful infection in most cases (Setliff, 2002). C. purpureum strain HQ1 was registered under the product name Mycotech Paste with the PMRA in 2002 (PMRA Reg. No. 27019) and the EPA in 2005 (EPA Reg. No. 74128-2). Registration of this strain with the PMRA ended in 2008. Another strain of this species, PFC 2139, was registered under the product name Chontrol Paste with the EPA in 2004 (EPA Reg. No. 74200-E/R) and with the PMRA in 2007 (PMRA Reg. No. 27823 and 29293). Both registrations are currently active and this product remains commercially available.

Another fungus, Puccinia thlaspeos, was registered with the EPA in 2002 under the product name Woad Warrior for control of Dyer's woad (Isatis tinctoria) (EPA Registration Number 734171 ). This fungus is an obligate parasite and requires a living host to reproduce, however, inoculum can be produced from dried and ground plant material of its target weed (Thomson and Kropp, 2004). This product is no longer commercially available (Bailey, 2014).

Alternaria destruens strain 059 was registered with the EPA in 2005 under the product names Smolder WP and Smolder G (EPA Reg. Nos. 34704-825 and 34704-824, respectively). This product, originally isolated from Cuscuta gronovii growing in unmanaged conditions in Wisconsin, is intended for control of dodder species (Cuscuta spp.) (Cook et al., 2009), however, it is not commercially available (Bailey, 2014).

A final bioherbicide that bears mentioning is DeVine, a formulation of the fungus Phytophthora palmivora (Kenney, 1986). This product was registered with the EPA in 1981 and again in 2006 (Bailey, 2014; EPA Reg No. 73049-9). P. palmivora was originally isolated from strangler vine (Morrenia odorata) in Florida and was used to control the same species in citrus orchards
(Ridings, 1986). Although this product was re-registered in 2006, it is no longer commercially available (Bailey, 2014).

\section{Biological Control of Weeds Using Bacteria}

A number of bacteria have also been investigated as potential biological weed control agents (Table 1). Of these, Pseudomonas fluorescens and Xanthomonas campestris have attracted the most attention. Biological weed control using bacteria has been suggested to have several advantages over the use of fungi, including more rapid growth of the bioherbicide agents (Johnson et al., 1996; Li et al., 2003), relatively simple propagation requirements ( $\mathrm{Li}$ et al., 2003), and high suitability for genetic modification through either mutagenesis or gene transfer (Johnson et al., 1996).

As mentioned above, $P$. fluorescens has received much of the attention as a biological weed control agent (Table 1). There are many strains of this species, some of which are beneficial to plants (Gamalero et al., 2005), whereas others are inhibitory (Banowetz et al., 2008). Among studies into the suppressive effects of $P$. fluorescens, three strains have been investigated in especially great detail, all of which have been observed to inhibit plant growth and/or germination through the production of extracellular metabolites (Kennedy et al., 1991; Quail et al., 2002; Banowetz et al., 2008).

Pseudomonas fluorescens strain D7, originally isolated from the rhizospheres of winter wheat (Triticum aestivum) and downy brome (Bromus tectorum) in Western Canada, has been observed to selectively inhibit growth and germination of a number of grassy weeds, most notably downy brome (Kennedy et al., 1991, 2001; Gealy et al., 1996). By selective removal of compounds from cell-free filtrates, the growth-inhibiting activity associated with this strain was attributed to a combination of extracellular peptides and a lipopolysaccharide, which were suggested to work in conjunction to express herbicidal activity (Gurusiddaiah et al., 1994). No subsequent reports regarding mechanism were found in the available literature.

Conversely, $P$. fluorescens strain WH6 has been observed to affect the germination of a much broader range of plant species, significantly inhibiting germination of all species tested (21 monocot species and 8 dicot species) with the exception of a modern corn (Zea mays) hybrid (Banowetz et al., 2008). The germination-inhibiting activity of the WH6 strain has been attributed to the production of a compound originally referred to as Germination Arrest Factor (GAF; Banowetz et al., 2008). The active component of GAF has been identified through nuclear magnetic resonance spectroscopy and mass spectrometry as 4formylaminooxy-L-vinylglycine (McPhail et al., 2010), and its biosynthesis has been proposed to begin with the amino acid homoserine (Halgren et al., 2013). This class of compounds, the oxyvinylglycines, has been shown to interfere with enzymes that utilize pyridoxal phosphate as a cofactor, including enzymes involved in nitrogen metabolism and biosynthesis of the plant hormone ethylene (Berkowitz et al., 2006; Halgren et al., 2013). Interestingly, GAF has also been recognized to express specific bactericidal activity against Erwinia amylovora, the bacterium that causes fire blight in orchards (Halgren et al., 2011). The 
genome sequence of $P$. fluorescens strain WH6 has been published (Kimbrel et al., 2010), and gene knockouts were used to identify several biosynthetic and regulatory genes involved in GAF/ 4formylaminooxy-L-vinylglycine production (Halgren et al., 2013; Okrent et al., 2014). Strain D7 was also included in the original investigation of strain WH6, however, as culture filtrates of strain D7 prepared in the same manner as WH6 did not possess germination-inhibiting activity the authors suggested that GAF was not responsible for the activity associated with strain D7 (Banowetz et al., 2008).

The production of extracellular metabolites with phytotoxic effects has also been observed in an additional $P$. fluorescens strain, referred to as BRG100, which has been recognized to have suppressive activity on the grassy weed green foxtail (Setaria viridis) (Quail et al., 2002; Caldwell et al., 2012). The herbicidal compounds produced by this species, referred to as pseudophomin $\mathrm{A}$ and $\mathrm{B}$, have been characterized through a combination of serial chromatography, high performance liquid chromatography (HPLC), thin layer chromatography (TLC), chemical degradation, and X-ray crystallography (Quail et al., 2002; Pedras et al., 2003). Unfortunately, neither the biosynthetic pathway involved in the production of these compounds nor the specific biochemical effects of these molecules on green foxtail have been characterized at this time. However, the full genome sequence of this strain has been published (Dumonceaux et al., 2014) and a detailed projection of the costs and technical requirements for the mass production of this biocontrol agent has been reported (Mupondwa et al., 2015).

The other bacterial species that has received much of the attention as a candidate biological weed control agent is Xanthomonas campestris (Table 1). Most notably within this species, the strain $X$. campestris pv. poae (JT-P482) was registered in Japan in 1997 for control of annual bluegrass (Poa annua) under the product name Camperico (Imaizumi et al., 1997; Tateno, 2000). The activity of this species is specific to Poa annua and Poa attenuata, and was not reported to affect other turf species tested (Imaizumi et al., 1997). A separate strain of X. campestris (isolate LVA-987) has also received attention as a potential control agent against horseweed (Conyza canadensis) (Boyette and Hoagland, 2015). No discovery of phytotoxic compounds was reported in any of the aforementioned investigations into application of $X$. campestris as a bioherbicide, however, compounds with phytotoxic activity have been previously isolated from the vitians pathovar of this species (Scala et al., 1996), and it is possible that phytotoxic metabolites play a role in the suppression of $\mathrm{Poa}$ annua and Conyza canadensis. Although the cause of host-plant suppression was not indicated in the above studies, the infection process of $X$. campestris pv. campestris $(X c c)$ in brassica crops has been well characterized. Briefly, Xcc can colonize the xylem of the host plant and use this pathway to spread throughout the organism (Duge de Bernonville et al., 2014). The success of Xcc in reaching the host xylem is contingent on its interaction with receptor proteins of the host plant that can recognize pathogen associated molecular patterns (PAMPs), potentially resulting in elicitation of plant defense responses such as programmed cell death and increased production of reactive oxygen (Guy et al., 2013).

\section{Biological Control of Weeds Using Viruses}

In select cases, viruses that affect weed species have also been considered as bioherbicide candidates. This strategy is more commonly considered for management of invasive species in broader ecosystems rather than specifically managed areas. Viruses have been suggested to be inappropriate candidates for inundative biological control due to their genetic variability and lack of host specificity (Kazinczi et al., 2006). Examples of viruses that have been investigated for the potential to control invasive or undesirable species include Tobacco Mild Green Mosaic Tobamovirus for control of tropical soda apple (Solanum viarum) in Florida (Ferrell et al., 2008; Diaz et al., 2014), and Araujia Mosaic Virus for control of moth plant (Araujia hortorum) in New Zealand (Elliott et al., 2009). A patent on the former biological control agent has been filed (Charudattan et al., 2009) and EPA approval for use on fenced-in pasture areas was granted in 2015 (EPA, 2015). A virus resembling Tobacco Rattle Virus has also been proposed as a control agent for Impatiens glandulifera, an invasive weed of concern in central and western Europe (Kollmann et al., 2007). Similarly, Óbuda Pepper Virus (ObPV) and Pepino Mosaic Virus (PepMV) have been proposed as agents to reduce overall populations of the weed Solanum nigrum (Kazinczi et al., 2006). The biological activities of viruses are very distinct from pathogenesis caused by bacteria or fungi, and may present additional opportunities for biological weed control in some situations.

\section{Real World Factors that Affect the Efficacy of Bioherbicides}

The research pipeline from the screening stage to field conditions faces a number of unique challenges (Figure 1). One commonly reported challenge is the need for continuous moisture availability during the period in which the biocontrol agent infects the plant (Auld et al., 1990; Schisler et al., 1991; Auld and Morin, 1995; Stewart-Wade and Boland, 2005; Boyette and Hoagland, 2015). In a review of bioherbicide technology published by Auld and Morin (1995), it was reported that dew periods of more than 12 hours are commonly necessary for bioherbicide candidates to successfully infect their hosts. A variety of techniques to provide this moisture have been tested, with varying degrees of success. In order to prolong the period of leaf wetness necessary for successful infection of dandelion by Phoma herbarum, several vegetable oil emulsions were included in aqueous inoculants, however, these additives were found to be phytotoxic, thus obscuring the benefit to infection that may have been caused by their addition (Stewart-Wade and Boland, 2005). Timing inoculant application to prolong the leaf wetness period (e.g., application at dawn or dusk) has also been suggested as a simple method of maximizing infection, although the success of this technique can be highly sensitive to environmental fluctuations (Auld and Morin, 1995). In some cases, solid inoculant media have also been investigated. The most common method for developing solid inoculant media is to propagate the candidate biological weed control species on grains which will subsequently be applied directly to the field or incorporated with other moisture-retaining materials 


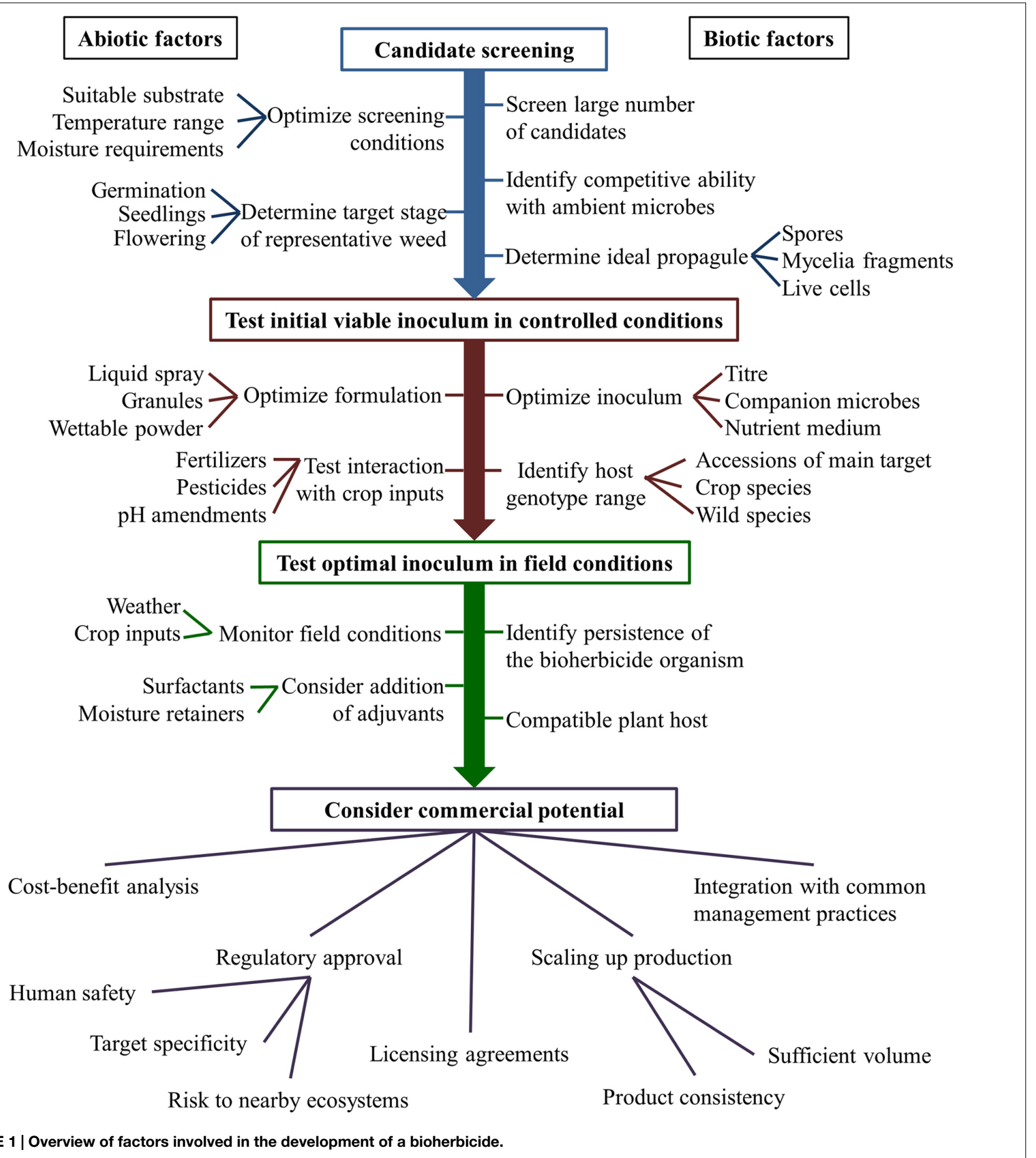

FIGURE 1 | Overview of factors involved in the development of a bioherbicide.

such as calcium alginate, oils or vermiculite (Auld et al., 2003). Granular applications have the advantage of prolonging the infield survival of introduced biological weed control agents through the provision of moisture and nutrients, however, they are also generally associated with a more gradual rate of infection (Auld et al., 2003).

The interplay of temperature and humidity also has a significant effect on the success or failure of infection by many pathogens
(Ghosheh, 2005) and may alter the efficacy of biological control agents (Casella et al., 2010; Figure 1). Cold air can retain less total moisture than warm air, and thus the relative humidity is more commonly elevated at lower temperatures. Elevated humidity is generally beneficial to successful bioherbicide colonization because it decreases evaporation rates, thus increasing the duration of leaf wetness following inoculant application (Casella et al., 2010). In investigating the efficacy of the biological weed 
control product Sarritor, it was found that infection rates were highest when the temperature remained below $20^{\circ} \mathrm{C}$ and the relative humidity was high (Siva, 2014). Similar requirements have been suggested by Auld et al. (1990), who observed that successful infection of spiny cocklebur (Xanthium spinosum) by biological weed control agent Colletotrichum orbiculare may have been contingent on elevated humidity. As with any species, most biological control species will have a fairly finite temperature range in which they can survive, as well as a narrower range in which their activity will be maximized. For example, Imaizumi et al. (1997) found that ambient temperatures below $25^{\circ} \mathrm{C}$ (day) and $20^{\circ} \mathrm{C}$ (night) caused decreased efficacy of Xanthomonas campestris pv. poae in the suppression of annual bluegrass (Poa annua). Similarly, the efficacy of $X$. campestris isolate LVA987 in controlling horseweed (Conyza canadensis) was found to require ambient temperatures between $20^{\circ} \mathrm{C}$ and $35^{\circ} \mathrm{C}$, with peak efficacy between $25^{\circ} \mathrm{C}$ and $35^{\circ} \mathrm{C}$ (Boyette and Hoagland, 2015). This parameter will be different for any given biological control candidate species and thus temperature and humidity should be tracked throughout any efficacy trials involving biological weed control agents.

Quorum sensing refers to the ability of a bacterium to differentially express genes based on its population density (Rutherford and Bassler, 2012). The effect of bacterial and fungal population densities can in some cases inform the behavior of these species, and in some cases affect whether a pathogen is virulent or latent (Bowden et al., 2013; Lu et al., 2014). This is an important factor in the characterization of potential bioherbicides, however, testing inoculant media with varying population densities (Figure 1) is not a common practice within the investigation of biological weed control strategies, nor is the phenomenon of quorum sensing commonly discussed in the related literature. However, apparent latent periods in the life cycle of biological weed control candidate species have been occasionally reported (Romero et al., 2001; Paynter et al., 2006), and it is possible that quorum sensing effects could explain these cases of asymptomatic infection.

It is possible that interactions with fertilizers and pesticides could affect the infectiousness of a candidate biological weed control agent (Boyetchko, 1997; Figure 1). For example, an investigation of the ability of $P$. macrostoma to control dandelions in turf found that co-application with a high rate of nitrogen fertilizer improved its efficacy, whereas co-application with phosphorus had no effect, and potassium sulfate decreased efficacy (Bailey et al., 2013).

\section{Challenges in Commercialization}

Despite the promise shown by many bioherbicides, few have achieved long-term commercial success, in part due to the challenges to achieving consistent efficacy in field conditions noted above. For example, amongst the fungal bioherbicides described in this review, only LockDown (C. gloeosporioides f.sp. aeschynomene) remains commercially available (Bailey, 2014). In the case of BioMal (C. gloeosporioides f.sp. malvae), the narrow target specificity (only round leaf mallow) of the product made for a market niche that was too small to cover production costs
(Cross and Polonenko, 1996). Additionally, significant challenges were encountered in maintaining product consistency while scaling up production volumes (Boyetchko et al., 2007). For these reasons, Philom Bios, the original commercial producer of this bioherbicide, discontinued its production in 1994, only 2 years after registration (Boyetchko et al., 2007). The strain was later licensed to Encore Technologies in 1998, however, challenges with maintaining product consistency under mass production led to the abandonment of the project (Boyetchko et al., 2007). In the case of Sarritor (S. minor strain IMI 344141), the commercial failure has been attributed to challenges with increasing production volume and product consistency, as well as inconsistent efficacy of the product due to the narrow range of environmental conditions in which successful infection will occur (Watson and Bailey, 2013). Unfortunately, the current commercial status of Camperico (X. campestris pv. poae JT-P482), described above, is unclear (Bailey, 2014).

\section{Future Directions}

\section{Mechanism of Action}

As noted above, the mechanism(s) behind the suppressive activity of a given biocontrol agent is in many cases only partially understood. Future research into the mechanisms underlying these effects will be important to achieve consistent efficacy with biocontrol agents, as well as to evaluate potential impacts on human and ecosystem health. This in turn will be of value to gaining regulatory approval. Additionally, understanding bioherbicidal mechanisms may generate novel chemical herbicides to overcome current resistance traits (Boyetchko et al., 2009), and will likely also be of peripheral value to the field of plant pathology.

\section{Transition to the Field}

Translating effects observed in a controlled environment to field conditions is a significant challenge to the development of successful biocontrol agents (Figure 1), and it is common for projects to conclude at this juncture. Thus, the development of new delivery formulations intended to improve the in-field stability of biocontrol agents is as important as the discovery of the agents themselves. Widespread testing of a given biocontrol agent in a variety of locations, similar to plant variety testing, is essential to understanding the feasibility of introducing that agent on a broad scale. Finally, the production of commercially relevant quantities of viable inoculum or culture extract must also be considered, as techniques employed in the laboratory are frequently impractical for industrial-scale production. Lessons from other industries such as pharmaceuticals and probiotic foods will likely be valuable in addressing this challenge.

\section{Extraction of Herbicidal Compounds}

As discussed earlier, in some cases a particular herbicidal compound can be extracted from a live culture (Kennedy et al., 1991; Quail et al., 2002; Banowetz et al., 2008). This strategy can yield a more stable control agent, the efficacy of which will not be contingent on the continued survival of a given organism in an 
uncontrolled environment. Although the differentiation between naturally and synthetically sourced pesticides may be arbitrary in terms of their potential effect on human and environmental health, such compounds will likely be more acceptable in the public eye than those produced through traditional chemistry.

\section{New Sources of Bioherbicide Candidates}

This review has focused on a limited number of genera which have received an especially great degree of attention as bioherbicide candidates for turf and field crop situations. Considering the degree of taxonomic diversity among microbes, there are opportunities to employ other genera as bioherbicides in the future. Most of the studies discussed in this review employed microbes that were originally isolated from diseased individuals within the population of a weed species (Kennedy et al., 1991; Neumann and Boland, 1999; Ghosheh, 2005). However, there are additional ecological niches from which potential biological weed control candidates can be discovered. For example, most plant species form relationships with a variety of microbes, referred to as endophytes, which colonize the internal environment of the plant without causing disease (Duan et al., 2013; Ali et al., 2014). There is evidence that endophytes can play a role in nutrient accumulation, drought tolerance and disease resistance (Compant et al., 2010; Johnston-Monje and Raizada, 2011; Mousa and Raizada, 2013). Growth-promoting endophytes have been shown to reduce weed populations in pastures by inoculating the desired grass species, enabling them to compete with weeds more effectively (Saikkonen et al., 2013; Vazquezde-Aldana et al., 2013). It has been reported that some plantinhabiting microbes will express host-specific behavior, acting as an endophyte in some plant species but as a pathogen in another (Gomes et al., 2013). Additionally, some endophytes have also been reported to produce compounds that are phytotoxic to non-host species (Waqas et al., 2013; Zhang et al., 2013; Li et al., 2014). These phenomena could potentially be applied to controlling undesirable weed species. Endophyte-based weed control may have unique advantages over the application of pathogens such as improved ability of candidate microbes to

\section{References}

Abu-Dieyeh, M. H., and Watson, A. K. (2006). Effect of turfgrass mowing height on biocontrol of dandelion with Sclerotinia minor. Biocontrol. Sci. Technol. 16, 509-524. doi: 10.1080/09583150500532725

Abu-Dieyeh, M. H., and Watson, A. K. (2007a). Efficacy of Sclerotinia minor for dandelion control: effect of dandelion accession, age and grass competition. Weed Res. 47, 63-72. doi: 10.1111/j.1365-3180.2007.00542.x

Abu-Dieyeh, M. H., and Watson, A. K. (2007b). Grass overseeding and a fungus combine to control Taraxacum officinale. J. Appl. Ecol. 44, 115-124. doi: 10.1111/j.1365-2664.2006.01247.x

Ali, S., Duan, J., Charles, T. C., and Glick, B. R. (2014). A bioinformatics approach to the determination of genes involved in endophytic behavior in Burkholderia spp. J. Theor. Biol. 343, 193-198. doi: 10.1016/j.jtbi.2013.10.007

Anderson, M. D., Hollingsworth, C. S., Vanzee, V., Coli, W. M., and Rhodes, M. (1996). Consumer response to integrated pest management and certification. Agric. Ecosyst. Environ. 60, 97-106. doi: 10.1016/s0167-8809(96)01097-3

Andolfi, A., Cimmino, A., Villegas-Fernandez, A. M., Tuzi, A., Santini, A., Melck, D., et al. (2013). Lentisone, a new phytotoxic anthraquinone produced by Ascochyta lentis, the causal agent of Ascochyta Blight in Lens culinaris. J. Agric. Food Chem. 61, 7301-7308. doi: 10.1021/jf4026663 persist in field conditions through having a more consistent ecological niche within their plant host, or the provision of other benefits to their host such as nutrient acquisition or disease resistance.

\section{Conclusion}

Although there are many challenges and constraints inherent in the development of biological herbicides, the increasing prevalence of both herbicide-resistant weeds (Green and Owen, 2011) and public concern with pesticide use (McNeil et al., 2010) creates a strong impetus for continued investigation in this field. These strategies will be of especially great value to organic production systems and to regions where cosmetic pesticide bans are in place. With continued investigation in this field, there is significant potential for the development of new weed control strategies that can be employed to delay herbicide resistance, produce food in accordance with consumer concerns, and reduce the environmental impact of modern agriculture and ecosystem management. Although there is a considerable number of candidate species that have been considered for this purpose, the major challenge to successful implementation of this strategy is the development of techniques to maintain consistent efficacy in field conditions.

\section{Author Contributions}

DPH conceived and wrote the manuscript, and MNR edited the manuscript. Both authors approved the final manuscript.

\section{Acknowledgments}

Funding: DPH was supported by scholarships from the OMAFRA HQP program, as well as the Hutt family, the Robb family and the Richmond family. This research was supported by grants to MNR from the Ontario Turfgrass Research Foundation (OTRF) and the Agriculture Adaptation Council (AAC) of Canada Growing Forward 2 Program.

Auld, B. A., McRae, C. F., and Say, M. M. (1988). Possible control of Xanthium spinosum by a fungus. Agric. Ecosyst. Environ. 21, 219-223. doi: 10.1016/01678809(88)90089-8

Auld, B. A., Say, M. M., Ridings, H. I., and Andrews, J. (1990). Field applications of Colletotrichum orbiculare to control Xanthium spinosum. Agric. Ecosyst. Environ. 32, 315-323. doi: 10.1016/0167-8809(90)90168-d

Auld, B. A., Hetherington, S. D., and Smith, H. E. (2003). Advances in bioherbicide formulation. Weed Biol. Manag. 3, 61-67. doi: 10.1046/j.1445-6664.2003.00086.x

Auld, B. A., and Morin, L. (1995). Constraints in the development of bioherbicides. Weed Technol. 9, 638-652.

Bailey, K. L. (2014). "The bioherbicide approach to weed control using plant pathogens," in Integrated Pest Management: Current Concepts and Ecological Perspective, ed. D. P. Abrol. (San Diego, CA: Elsevier), 245-266.

Bailey, K. L., Boyetchko, S. M., and Langle, T. (2010). Social and economic drivers shaping the future of biological control: a Canadian perspective on the factors affecting the development and use of microbial biopesticides. Biol. Control 52, 221-229. doi: 10.1016/j.biocontrol.2009.05.003

Bailey, K. L., Falk, S., Derby, J. A., Melzer, M., and Boland, G. J. (2013). The effect of fertilizers on the efficacy of the bioherbicide, Phoma macrostoma, to control dandelions in turfgrass. Biol. Control 65, 147-151. doi: 10.1016/j.biocontrol.2013.01.003 
Bailey, K. L., Pitt, W. M., Falk, S., and Derby, J. (2011). The effects of Phoma macrostoma on non-target plant and target weed species. Biol. Control 58, 379-386. doi: 10.1016/j.biocontrol.2011.06.001

Banowetz, G. M., Azevedo, M. D., Armstrong, D. J., Halgren, A. B., and Mills, D. I. (2008). Germination-Arrest Factor (GAF): biological properties of a novel, naturally-occurring herbicide produced by selected isolates of rhizosphere bacteria. Biol. Control 46, 380-390. doi: 10.1016/j.biocontrol.2008.04.016

Barnickel, B., and Schobert, R. (2010). Toward the macrocidins: macrocyclization via Williamson etherification of a phenolate. J. Org. Chem. 75, 6716-6719. doi: $10.1021 /$ jo $101416 \mathrm{x}$

Bazoche, P., Combris, P., Giraud-Heraud, E., Pinto, A., Bunte, F., and Tsakiridou, E. (2014). Willingness to pay for pesticide reduction in the EU: nothing but organic? Eur. Rev. Agric. Econ. 41, 87-109. doi: 10.1093/erae/jbt011

Beckie, H. J. (2011). Herbicide-resistant weed management: focus on glyphosate. Pest. Manag. Sci. 67, 1037-1048. doi: 10.1002/ps.2195

Beckie, H. J., Thomas, A. G., and Legere, A. (1999). Nature, occurrence, and cost of herbicide-resistant green foxtail (Setaria viridis) across Saskatchewan ecoregions. Weed Technol. 13, 626-631.

Belair, G., Koppenhofer, A. M., Dionne, J., and Simard, L. (2010). Current and potential use of pathogens in the management of turfgrass insects as affected by new pesticide regulations in North America. Int. J. Pest Manag. 56, 51-60. doi: 10.1080/09670870903076012

Berkowitz, D. B., Charette, B. D., Karukurichi, K. R., and Mcfadden, J. M. (2006). Alpha-vinylic amino acids: occurrence, asymmetric synthesis, and biochemical mechanisms. Tetrahedron Asymmetry 17, 869-882. doi: 10.1016/j.tetasy.2006.02.026

Bouras, N., and Strelkov, S. E. (2008). The anthraquinone catenarin is phytotoxic and produced in leaves and kernels of wheat infected by Pyrenophora triticirepentis. Physiol. Mol. Plant Pathol. 72, 87-95. doi: 10.1016/j.pmpp.2008. 06.001

Bowden, S. D., Eyres, A., Chung, J. C. S., Monson, R. E., Thompson, A., Salmond, G. P. C., et al. (2013). Virulence in Pectobacterium atrosepticum is regulated by a coincidence circuit involving quorum sensing and the stress alarmone, (p)ppGpp. Mol. Microbiol. 90, 457-471. doi: 10.1111/mmi.12369

Boyetchko, S. M. (1997). Principles of biological weed control with microorganisms. Hortscience 32, 201-205.

Boyetchko, S. M., Bailey, K. L., and De Clerck-Floate, R. A. (2009). Current biological weed control agents - their adoption and future prospects. Prairie Soils Crops J. 2, 38-45.

Boyetchko, S. M., Bailey, K. L., Hynes, R. K., and Peng, G. (2007). "Development of the mycoherbicide, BioMal (R)," in Biological Control: A Global Perspective, eds. C. Vincent, M. S. Goettel, and G. Lazarovits. (Oxon: CABI Publishing, 2007), 274-283.

Boyette, C. D. (1991). Host range and virulence of Colletotrichum truncatum, a potential mycoherbicide for hemp sesbania (Sesbania exaltata). Plant Dis. 75 , 62-64.

Boyette, C. D., and Hoagland, R. E. (2015). Bioherbicidal potential of Xanthomonas campestris for controlling Conyza canadensis. Biocontrol Sci. Technol. 25, 229-237. doi: 10.1080/09583157.2014.966650

Boyette, C. D., Gealy, D., Hoagland, R. E., Vaughn, K. C., and Bowling, A. J. (2011). Hemp sesbania (Sesbania exaltata) control in rice (Oryza sativa) with the bioherbicidal fungus Colletotrichum gloeosporioides f.sp. aeschynomene formulated in an invert emulsion. Biocontrol. Sci. Technol. 21, 1399-1407. doi: 10.1080/09583157.2011.625398

Boyette, C. D., Hoagland, R. E., and Weaver, M. A. (2007). Biocontrol efficacy of Colletotrichum truncatum for hemp sesbania (Sesbania exaltata) is enhanced with unrefined corn oil and surfactant. Weed Biol. Manag. 7, 70-76. doi: 10.1111/j.1445-6664.2006.00230.x

Briere, S. C., Watson, A. K., and Hallett, S. G. (2000). Oxalic acid production and mycelial biomass yield of Sclerotinia minor for the formulation enhancement of a granular turf bioherbicide. Biocontrol Sci. Technol. 10, 281-289. doi: 10.1080/09583150050044556

Burnett, H. C., Tucker, D. P. H., Patterson, M. E., and Ridings, W. H. (1973). Biological control of milkweed vine with a race of Phytophthora citrophthora. Proc. Florida State Hortic. Soc. 86, 111-115.

Caldwell, C. J., Hynes, R. K., Boyetchko, S. M., and Korber, D. R. (2012). Colonization and bioherbicidal activity on green foxtail by Pseudomonas fluorescens BRG100 in a pesta formulation. Can. J. Microbiol. 58, 1-9. doi: 10.1139/w11-109
Casella, F., Charudattan, R., and Vurro, M. (2010). Effectiveness and technological feasibility of bioherbicide candidates for biocontrol of green foxtail (Setaria viridis). Biocontrol Sci. Technol. 20, 1027-1045. doi: 10.1080/09583157.2010.502293

Cessna, S. G., Sears, V. E., Dickman, M. B., and Low, P. S. (2000). Oxalic acid, a pathogenicity factor for Sclerotinia sclerotiorum, suppresses the oxidative burst of the host plant. Plant Cell 12, 2191-2199. doi: 10.1105/tpc.12.11.2191

Charudattan, R. (2001). Biological control of weeds by means of plant pathogens: significance for integrated weed management in modern agro-ecology. Biocontrol 46, 229-260. doi: 10.1023/a:1011477531101

Charudattan, R., Pettersen, M. S., and Hiebert, E. (2009). Use of Tobacco Mild Green Mosaic Virus (TMGMV) Mediated Lethal Hypersensitive Response (HR) as a Novel Method of Weed Control. U.S. Patent No US7494955 B2. Washington, DC: U.S. Patent and Trademark Office.

Cimmino, A., Andolfi, A., Zonno, M. C., Avolio, F., Santini, A., Tuzi, A., et al. (2013). Chenopodolin: a phytotoxic unrearranged ent-pimaradiene diterpene produced by Phoma chenopodicola, a fungal pathogen for Chenopodium album biocontrol. J. Nat. Prod. 76, 1291-1297. doi: 10.1021/np400218z

Compant, S., Clement, C., and Sessitsch, A. (2010). Plant growth-promoting bacteria in the rhizo- and endosphere of plants: their role, colonization, mechanisms involved and prospects for utilization. Soil Biol. Biochem. 42, 669-678. doi: 10.1016/j.soilbio.2009.11.024

Cook, J. C., Charudattan, R., Zimmerman, T. W., Rosskopf, E. N., Stall, W. M., and MacDonald, G. E. (2009). Effects of Alternaria destruens, glyphosate, and ammonium sulfate individually and integrated for control of dodder (Cuscuta pentagona). Weed Technol. 23, 550-555. doi: 10.1614/wt-08-019.1

Cross, J. V., and Polonenko, D. R. (1996). An industry perspective on registration and commercialization of biocontrol agents in Canada. Can. J. Plant Pathol. Rev. Can. Phytopathol. 18, 446-454.

Dane, F., and Shaw, J. J. (1996). Survival and persistence of bioluminescent Xanthomonas campestris pv. campestris on host and non-host plants in the field environment. J. Appl. Bacteriol. 80, 73-80. doi: 10.1111/j.13652672.1996.tb03192.x

Daniel, J. T., Templeton, G. E., Smith, R. J., and Fox, W. T. (1973). Biological control of northern jointvetch in rice with an endemic fungal disease. Weed Sci. 21, 303-307.

Darmency, H. (2013). Pleiotropic effects of herbicide-resistance genes on crop yield: a review. Pest. Manag. Sci. 69, 897-904. doi: 10.1002/ps.3522

Diaz, R., Manrique, V., Hibbard, K., Fox, A., Roda, A., Gandolfo, D., et al. (2014). Successful biological control of tropical soda apple (Solanales: Solanaceae) in Florida: a review of key program components. Florida Entomol. 97, 179-190. doi: 10.1653/024.097.0124

Duan, J. L., Li, X. J., Gao, J. M., Wang, D. S., Yan, Y., and Xue, Q. H. (2013). Isolation and identification of endophytic bacteria from root tissues of Salvia miltiorrhiza Bge. and determination of their bioactivities. Ann. Microbiol. 63, 1501-1512. doi: 10.1007/s13213-013-0614-0

Duge de Bernonville, T., Noel, L. D., Sancristobal, M., Danoun, S., Becker, A., Soreau, P., et al. (2014). Transcriptional reprogramming and phenotypical changes associated with growth of Xanthomonas campestris pv. campestris in cabbage xylem sap. FEMS Microbiol. Ecol. 89, 527-541. doi: 10.1111/15746941.12345

Dumonceaux, T. J., Town, J., Links, M. G., and Boyetchko, S. (2014). High-quality draft genome sequence of Pseudomonas sp. BRG100, a strain with bioherbicidal properties against Setaria viridis (green foxtail) and other pests of agricultural significance. Genome Announc. 2, 1-2. doi: 10.1128/genomeA.00995-14

Elliott, M. S., Massey, B., Cui, X., Hiebert, E., Charudattan, R., Waipara, N., et al. (2009). Supplemental host range of Araujia mosaic virus, a potential biological control agent of moth plant in New Zealand. Australas. Plant Pathol. 38, 603-607. doi: 10.1071/ap09046

EPA. (2002). Biopesticides Registration Action Document: Puccinia thlaspeos 'Strain Woad'. PC Code 006489. United States Environmental Protection Agency. Available at: http://www.epa.gov/opp00001/chem search/reg_actions/registration/decision_PC-006489_1-Jun-02.pdf (accessed August 18, 2015)

EPA. (2004). Biopesticides Registration Action Document: Chondrostereum purpureum Strain PFC 2139. PC Code 081308. United States Environmental Protection Agency. Available at: http://www.epa.gov/pesticides/chem search/reg_actions/registration/decision_PC-081308_20-Sep-04.pdf (accessed August 18, 2015) 
EPA. (2005). Biopesticides Registration Action Document: Alternaria destruens Strain 059. PC Code 028301. United States Environmental Protection Agency. Available at: http://www.epa.gov/opp00001/chem_search/reg_actions/ registration/decision_PC-028301_18-May-05.pdf (accessed August 18, 2015)

EPA. (2014). New Biopesticide Active Ingredients. Available at: http://www.epa.gov/ oppbppd1/biopesticides/product_lists/new_ai_2010.html (accessed July 22, 2015).

EPA. (2015). Biopesticides Registration Action Document: Tobacco Mild Green Mosaic Tobamovirus Strain U2. PC Code: 056705. United States Environmental Protection Agency. Available at: http://www.regulations.gov/\#! documentDetail;D=EPA-HQ-OPP-2013-0759-0017 (accessed August 18, 2015)

European Parliament. (2014). Commission Implementing Regulation (EU) No 540/2011 of 25 May 2011 Implementing Regulation (EC) No 1107/2009 of the European Parliament and of the Council as Regards the List of Approved Active Substances. Available at: http://eur-lex.europa.eu/legal-content/EN/TXT/ PDF/?uri=CELEX:02011R0540-20140901\&from=EN (accessed August 18, 2015)

Evans, H. C., Seier, M. K., Derby, J. A., Falk, S., and Bailey, K. L. (2013). Tracing the origins of White Tip disease of Cirsium arvense and its causal agent, Phoma macrostoma. Weed Res. 53, 42-52. doi: 10.1111/j.1365-3180.2012.00951.x

Ferrell, J., Charudattan, R., Elliott, M., and Hiebert, E. (2008). Effects of selected herbicides on the efficacy of Tobacco mild green mosaic virus to control tropical soda apple (Solanum viarum). Weed Sci. 56, 128-132. doi: 10.1614/ ws-07-083.1

Font, M. I., Cordoba-Selles, M. C., Cebrian, M. C., Herrera-Vasquez, J. A., AlfaroFernandez, A., Boubaker, A., et al. (2009). First report of Tobacco mild green mosaic virus infecting Capsicum annuum in Tunisia. Plant Dis. 93, 761-761. doi: 10.1094/pdis-93-7-0761b

Gadermaier, G., Hauser, M., and Ferreira, F. (2014). Allergens of weed pollen: an overview on recombinant and natural molecules. Methods 66, 55-66. doi: 10.1016/j.ymeth.2013.06.014

Gamalero, E., Lingua, G., Tombolini, R., Avidano, L., Pivato, B., and Berta, G. (2005). Colonization of tomato root seedling by Pseudomonas fluorescens 92rkG5: spatio-temporal dynamics, localization, organization, viability, and culturability. Microb. Ecol. 50, 289-297. doi: 10.1007/s00248-004-0149-9

Gan, P., Ikeda, K., Irieda, H., Narusaka, M., O'Connell, R. J., Narusaka, Y., et al. (2013). Comparative genomic and transcriptomic analyses reveal the hemibiotrophic stage shift of Colletotrichum fungi. New Phytol. 197, 1236-1249. doi: 10.1111/nph.12085

Gealy, D. R., Gurusiddaiah, S., Ogg, A. G., and Kennedy, A. C. (1996). Metabolites from Pseudomonas fluorescens strain D7 inhibit downy brome (Bromus tectorum) seedling growth. Weed Technol. 10, 282-287.

Ghosheh, H. Z. (2005). Constraints in implementing biological weed control: a review. Weed Biol. Manag. 5, 83-92. doi: 10.1111/j.1445-6664.2005.00163.x

Gomes, R. R., Glienke, C., Videira, S. I. R., Lombard, L., Groenewald, J. Z., and Crous, P. W. (2013). Diaporthe: a genus of endophytic, saprobic and plant pathogenic fungi. Persoonia 31, 1-41. doi: 10.3767/003158513x666844

Graupner, P. R., Carr, A., Clancy, E., Gilbert, J., Bailey, K. L., Derby, J. A., et al. (2003). The macrocidins: novel cyclic tetramic acids with herbicidal activity produced by Phoma macrostoma. J. Nat. Prod. 66, 1558-1561. doi: $10.1021 / \mathrm{np} 030193 \mathrm{e}$

Green, J. M., and Owen, M. D. K. (2011). Herbicide-resistant crops: utilities and limitations for herbicide-resistant weed management. J. Agric. Food Chem. 59, 5819-5829. doi: 10.1021/jf101286h

Grossmann, K. (2010). Auxin herbicides: current status of mechanism and mode of action. Pest. Manag. Sci. 66, 113-120. doi: 10.1002/ps.1860

Gurusiddaiah, S., Gealy, D. R., Kennedy, A. C., and Ogg, A. G. (1994). Isolation and characterization of metabolites from Pseudomonas fluorescens D7 for control of downy brome (Bromus tectorum). Weed Sci. 42, 492-501.

Guy, E., Lautier, M., Chabannes, M., Roux, B., Lauber, E., Arlat, M., et al. (2013). xopAC-triggered immunity against Xanthomonas depends on Arabidopsis receptor-like cytoplasmic kinase genes PBL2 and RIPK. PLoS ONE 8:e73469. doi: 10.1371/journal.pone.0073469

Halgren, A., Azevedo, M., Mills, D., Armstrong, D., Thimmaiah, M., McPhail, K., et al. (2011). Selective inhibition of Erwinia amylovora by the herbicidally active germination-arrest factor (GAF) produced by Pseudomonas bacteria. J. Appl. Microbiol. 111, 949-959. doi: 10.1111/j.1365-2672.2011.05098.x

Halgren, A., Maselko, M., Azevedo, M., Mills, D., Armstrong, D., and Banowetz, G. (2013). Genetics of germination-arrest factor (GAF) production by
Pseudomonas fluorescens WH6: identification of a gene cluster essential for GAF biosynthesis. Microbiology 159, 36-45. doi: 10.1099/mic.0.062166-0

Harata, K., and Kubo, Y. (2014). Ras GTPase activating protein CoIral is involved in infection-related morphogenesis by regulating cAMP and MAPK signaling pathways through CoRas2 in Colletotrichum orbiculare. PLoS ONE 9:e109045. doi: 10.1371/journal.pone.0109045

Heap, I. (2015). The International Survey of Herbicide Resistant Weeds. Available at: www.weedscience.org (accessed June 16, 2015).

Hoagland, R. E., Boyette, C. D., Weaver, M. A., and Abbas, H. K. (2007). Bioherbicides: research and risks. Toxin Rev. 26, 313-342. doi: 10.1080/15569540701603991

Hynes, R. K., Chumala, P. B., Hupka, D., and Peng, G. (2010). A complex coacervate formulation for delivery of Colletotrichum truncatum 00-003B1. Weed Technol. 24, 185-192. doi: 10.1614/wt-d-09-00008.1

Imaizumi, S., Nishino, T., Miyabe, K., Fujimori, T., and Yamada, M. (1997). Biological control of annual bluegrass (Poa annua L.) with a Japanese isolate of Xanthomonas campestris pv. poae (JT-P482). Biol. Control 8, 7-14. doi: 10.1006/bcon. 1996.0475

Johnson, D. R., Wyse, D. L., and Jones, K. J. (1996). Controlling weeds with phytopathogenic bacteria. Weed Technol. 10, 621-624.

Johnston-Monje, D., and Raizada, M. N. (2011). "Plant and endophyte relationships: nutrient management," in Comprehensive Biotechnology, ed. M. Moo-Young, 2nd Edn. (Amsterdam, the Netherlands: Elsevier), 713-727.

Kazinczi, G., Lukacs, D., Takacs, A., Horvath, J., Gaborjanyi, R., Nadasy, M., et al. (2006). Biological decline of Solanum nigrum due to virus infections. J. Plant Dis. Protect. 325-330.

Kennedy, A. C., Elliott, L. F., Young, F. L., and Douglas, C. L. (1991). Rhizobacteria suppressive to the weed downy brome. Soil Sci. Soc. Am. J. 55, 722-727.

Kennedy, A. C., Johnson, B. N., and Stubbs, T. L. (2001). Host range of a deleterious rhizobacterium for biological control of downy brome. Weed Sci. 49, 792-797. doi: 10.1614/0043-1745(2001)049[0792:hroadr]2.0.co;2

Kenney, D. S. (1986). DeVine-The way it was developed-An industrialist's view. Weed Sci. 34, 15-16.

Kimbrel, J. A., Givan, S. A., Halgren, A. B., Creason, A. L., Mills, D. I., Banowetz, G. M., et al. (2010). An improved, high-quality draft genome sequence of the Germination-Arrest Factor-producing Pseudomonas fluorescens WH6. BMC Genomics 11:522. doi: 10.1186/1471-2164-11-522

Knopper, L. D., and Lean, D. R. S. (2004). Carcinogenic and genotoxic potential of turf pesticides commonly used on golf courses. J. Toxicol. Environ. Health Part B Crit. Rev. 7, 267-279. doi: 10.1080/10937400490452697

Kollmann, J., Banuelos, M. J., and Nielsen, S. L. (2007). Effects of virus infection on growth of the invasive alien Impatiens glandulifera. Preslia 79, 33-44.

Li, H., Xiao, J., Gao, Y. Q., Tang, J. J., Zhang, A. L., and Gao, J. M. (2014) Chaetoglobosins from Chaetomium globosum, an endophytic fungus in Ginkgo biloba, and their phytotoxic and cytotoxic activities. J. Agric. Food Chem. 62, 3734-3741. doi: 10.1021/jf500390h

Li, Y. Q., Sun, Z. L., Zhuang, X. F., Xu, L., Chen, S. F., and Li, M. Z. (2003). Research progress on microbial herbicides. Crop Protect. 22, 247-252. doi: 10.1016/s0261-2194(02)00189-8

Lovic, B. R., Dewey, S. A., Thomson, S. V., and Evans, J. O. (1988). Puccinia thlaspeos a possible biocontrol agent for Dyers woad. Proc. West. Soc. Weed Sci. 41, 55-57.

Lu, Y., Su, C., Unoje, O., and Liu, H. P. (2014). Quorum sensing controls hyphal initiation in Candida albicans through Ubrl-mediated protein degradation. Proc. Natl. Acad. Sci. U.S.A. 111, 1975-1980. doi: 10.1073/pnas. 1318690111

Magro, P., Marciano, P., and Dilenna, P. (1984). Oxalic acid production and its role in pathogenesis of Sclerotinia sclerotiorum. FEMS Microbiol. Lett. 24, 9-12. doi: 10.1111/j.1574-6968.1984.tb01234.x

McNeil, J. N., Cotnoir, P. A., Leroux, T., Laprade, R., and Schwartz, J. L. (2010). A Canadian national survey on the public perception of biological control. Biocontrol 55, 445-454. doi: 10.1007/s10526-010-9273-2

McPhail, K. L., Armstrong, D. J., Azevedo, M. D., Banowetz, G. M., and Mills, D. I. (2010). 4-Formylaminooxyvinylglycine, an herbicidal germination-arrest factor from Pseudomonas rhizosphere bacteria. J. Nat. Prod. 73, 1853-1857. doi: $10.1021 / \mathrm{np} 1004856$

Melzer, M. S., Smith, E. A., and Boland, G. J. (1997). Index of plant hosts of Sclerotinia minor. Can. J. Plant Pathol. Rev. Can. Phytopathol. 19, 272-280.

Menaria, B. L. (2007). Bioherbicides: an eco-friendly approach to weed management. Curr. Sci. 92, 10-11. 
Mithila, J., Hall, J. C., Johnson, W. G., Kelley, K. B., and Riechers, D. E. (2011). Evolution of resistance to auxinic herbicides: historical perspectives, mechanisms of resistance, and implications for broadleaf weed management in agronomic crops. Weed Sci. 59, 445-457. doi: 10.1614/ws-d-1100062.1

Mo, X. H., Li, Q. L., and Ju, J. H. (2014). Naturally occurring tetramic acid products: isolation, structure elucidation and biological activity. Rsc. Adv. 4, 50566-50593. doi: $10.1039 / \mathrm{c} 4 \mathrm{ra} 09047 \mathrm{k}$

Mortensen, K. (1988). The potential of an endemic fungus, Colletotrichum gloeosporioides, for biological control of round-leaved mallow (Malva pusilla) and velvetleaf (Abutilon theophrasti). Weed Sci. 36, 473-478.

Mousa, W. K., and Raizada, M. N. (2013). The diversity of anti-microbial secondary metabolites produced by fungal endophytes: an interdisciplinary perspective. Front. Microbiol. 4:65. doi: 10.3389/fmicb.2013.00065

Mupondwa, E., Li, X., Boyetchko, S., Hynes, R., and Geissler, J. (2015). Technoeconomic analysis of large scale production of pre-emergent Pseudomonas fluorescens microbial bioherbicide in Canada. Bioresour. Technol. 175, 517-528. doi: 10.1016/j.biortech.2014.10.130

Neumann Brebaum, S. (1998). Development of an Inundative Biological Weed Control Strategy for Taraxacum Officinale Weber in Turf. Ph. D. thesis, Guelph, ON, Canada: University of Guelph.

Neumann, S., and Boland, G. J. (1999). Influence of selected adjuvants on disease severity by Phoma herbarum on dandelion (Taraxacum officinale). Weed Technol. $13,675-679$.

Oerke, E. C. (2006). Crop losses to pests. J. Agric. Sci. 144, 31-43. doi: $10.1017 / \mathrm{s} 0021859605005708$

Okrent, R. A., Halgren, A. B., Azevedo, M. D., Chang, J. H., Mills, D. I., Maselko, M., et al. (2014). Negative regulation of germination-arrest factor production in Pseudomonas fluorescens WH6 by a putative extracytoplasmic function sigma factor. Microbiology 160, 2432-2442. doi: 10.1099/mic.0.080317-0

Papayiannis, L. C., Kokkinos, C. D., and Alfaro-Fernandez, A. (2012). Detection, characterization and host range studies of Pepino mosaic virus in Cyprus. Eur. J. Plant Pathol. 132, 1-7. doi: 10.1007/s10658-011-9854-7

Paynter, Q., Waipara, N., Peterson, P., Hona, S., Fowler, S., Gianotti, A., et al. (2006). The impact of two introduced biocontrol agents, Phytomyza vitalbae and Phoma clematidina, on Clematis vitalba in New Zealand. Biol. Control 36, 350-357. doi: 10.1016/j.biocontrol.2005.09.011

Pedras, M. S. C., Ismail, N., Quail, J. W., and Boyetchko, S. M. (2003). Structure, chemistry, and biological activity of pseudophomins A and B, new cyclic lipodepsipeptides isolated from the biocontrol bacterium Pseudomonas fluorescens. Phytochemistry 62, 1105-1114. doi: 10.1016/s0031-9422(02) 00617-9

Pitt, W. M., Bailey, K. L., Fu, Y. B., and Peterson, G. W. (2012). Biological and genetic characterisation of Phoma macrostoma isolates with bioherbicidal activity. Biocontrol Sci. Technol. 22, 813-835. doi: 10.1080/09583157.2012.691159

PMRA. (2002). Proposed Regulatory Decision Document PRDD2002-01: Chondrostereum Purpureum (HQ1). Health Canada. Ottawa, ON: Health Canada.

PMRA. (2006). "Re-evaluation of Colletotrichum gloeosporioides f.sp. malvae [CGM]" REV2006-10. Ottawa, ON: Health Canada.

PMRA. (2010). “Sclerotinia minor Strain IMI 344141” RD2010-08. Health Canada. Ottawa, ON: Health Canada.

Quail, J. W., Ismail, N., Pedras, M. S. C., and Boyetchko, S. M. (2002). Pseudophomins A and B, a class of cyclic lipodepsipeptides isolated from a Pseudomonas species. Acta Crystallogr. C Crystal Struct. Commu. 58, o268-o271. doi: $10.1107 / \mathrm{s} 0108270102004432$

Quereshi, S., Khan, N. A., and Pandey, A. K. (2011). Anthraquinone pigment with herbicidal potential from Phoma herbarum FGCC\#54. Chem. Nat. Comp. 47, 521-523. doi: 10.1007/s10600-011-9986-1

Ray, P., and Vijayachandran, L. S. (2013). Evaluation of indigenous fungal pathogens from horse purslane (Trianthema portulacastrum) for their relative virulence and host range assessments to select a potential mycoherbicidal agent. Weed Sci. 61, 580-585. doi: 10.1614/ws-d-12-00076.1

Riddle, G. E., Burpee, L. L., and Boland, G. J. (1991). Virulence of Sclerotinia sclerotiorum and S. minor on dandelion (Taraxacum officinale). Weed Sci. 39, 109-118.

Ridings, W. H. (1986). Biological control of stranglervine in citrus-A researcher's view. Weed Sci. 34, 31-32.
Ridings, W. H., Mitchell, D. J., Schoulties, C. L., and El-Gholl, N. E. (1973). Biological control of milkweed vine in Florida citrus groves with a pathotype of Phytophthora citrophthora. Proc. Int. Sympos. Biol. Control Weeds 4, 224-240.

Romero, A., Carrion, G., and Rico-Gray, V. (2001). Fungal latent pathogens and endophytes from leaves of Parthenium hysterophorus (Asteraceae). Fungal Diversity 7, 81-87.

Rutherford, S. T., and Bassler, B. L. (2012). Bacterial quorum sensing: its role in virulence and possibilities for its control. Cold Spring Harbor Perspect. Med. 2 , 1-26. doi: 10.1101/cshperspect.a012427

Saikkonen, K., Ruokolainen, K., Huitu, O., Gundel, P. E., Piltti, T., Hamilton, C. E., et al. (2013). Fungal endophytes help prevent weed invasions. Agric. Ecosyst. Environ. 165, 1-5. doi: 10.1016/j.agee.2012.12.002

Sammons, R. D., and Gaines, T. A. (2014). Glyphosate resistance: state of knowledge. Pest. Manag. Sci. 70, 1367-1377. doi: 10.1002/ps.3743

Sandrin, T. R., Tebeest, D. O., and Weidemann, G. J. (2003). Soybean and sunflower oils increase the infectivity of Colletotrichum gloeosporioides $\mathrm{f} . \mathrm{sp}$. aeschynomene to northern jointvetch. Biol. Control 26, 244-252. doi: 10.1016/s10499644(02)00156-1

Scala, F., Evidente, A., Coppola, L., Capasso, R., Lorito, M., and Zoina, A. (1996). Identification and phytotoxicity of 3-methylthiopropanoic and trans3-methylthiopropenoic acids produced in culture by Xanthomonas campestris pv. vitians. J. Phytopathol. Phytopathol. Z. 144, 325-329. doi: 10.1111/j.14390434.1996.tb01537.x

Schaad, N. W., Song, W., Hutcheson, S., and Dane, F. (2001). Gene tagging systems for polymerase chain reaction based monitoring of bacteria released for biological control of weeds. Can. J. Plant Pathol. Rev. Can. Phytopathol. 23, 36-41. doi: 10.1080/07060660109506906

Schisler, D. A., Howard, K. M., and Bothast, R. J. (1991). Enhancement of disease caused by Colletotrichum truncatum in Sesbania exaltata by coinoculating with epiphytic bacteria. Biol. Control 1, 261-268. doi: 10.1016/1049-9644(91)90076-c

Schobert, R., and Schlenk, A. (2008). Tetramic and tetronic acids: an update on new derivatives and biological aspects. Bioorg. Med. Chem. 16, 4203-4221. doi: 10.1016/j.bmc.2008.02.069

Setliff, E. C. (2002). The wound pathogen Chondrostereum purpureum, its history and incidence on trees in North America. Aust. J. Bot. 50, 645-651. doi: 10.1071/bt01058

Shaw, R. H., Bryner, S., and Tanner, R. (2009). The life history and host range of the Japanese knotweed psyllid, Aphalara itadori Shinji: potentially the first classical biological weed control agent for the European Union. Biol. Control 49, 105-113. doi: 10.1016/j.biocontrol.2009.01.016

Simmons, E. G. (1998). Alternaria themes and variations (224-225). Mycotaxon 68, 417-427.

Siva, C. (2014). Examining Alternative Strategies for Broadleaf Weed Management in Home Lawns. Ph.D. thesis, Guelph, ON, Canada: University of Guelph.

Skipp, R. A., Bourdot, G. W., Hurrell, G. A., Chen, L. Y., Wilson, D. J., and Saville, D. J. (2013). Verticillium dahliae and other pathogenic fungi in Cirsium arvense from New Zealand pastures: occurrence, pathogenicity and biological control potential. N. Z. J. Agric. Res. 56, 1-21. doi: 10.1080/00288233.2012.732092

Smith, J., Wherley, B., Reynolds, C., White, R., Senseman, S., and Falk, S. (2015). Weed control spectrum and turfgrass tolerance to bioherbicide Phoma macrostoma. Int. J. Pest Manag. 61, 91-98. doi: 10.1080/09670874.2015.1014450

Stewart-Wade, S. M., and Boland, G. J. (2005). Oil emulsions increase efficacy of Phoma herbarum to control dandelion but are phytotoxic. Biocontrol Sci. Technol. 15, 671-681. doi: 10.1080/09583150500136873

Stewart-Wade, S. M., Neumann, S., Collins, L. L., and Boland, G. J. (2002). The biology of Canadian weeds. 117. Taraxacum officinale G. H. Weber ex Wiggers. Can. J. Plant Sci. 82, 825-853. doi: 10.4141/P01-010

Tateno, A. (2000). Herbicidal Composition for the Control of Annual Bluegrass. U.S. Patent No 6162763 A. Washington, DC: U.S. Patent and Trademark Office.

TeBeest, D. O. (1996). "Biological control of weeds with plant pathogens and microbial pesticides," in Advances in Agronomy, Vol 56, ed. D. L. Sparks. (San Diego: Elsevier Academic Press Inc), 115-137.

Thomson, S. V., and Kropp, B. R. (2004). Production of Puccinia thlaspeos 'woad' strain inoculum using traditional farming equipment. Phytopathology 94, S155-S155.

Tobias, I., Rast, A. T. B., and Maat, D. Z. (1982). Tobamoviruses of pepper, eggplant, and tobacco - comparative host reactions and serological relationships. Netherlands J. Plant Pathol. 88, 257-268. doi: 10.1007/bf02000131 
Vazquez-de-Aldana, B. R., Zabalgogeazcoa, I., Garcia-Ciudad, A., and GarciaCriado, B. (2013). An Epichloë endophyte affects the competitive ability of Festuca rubra against other grassland species. Plant Soil 362, 201-213. doi: 10.1007/s11104-012-1283-7

Waqas, M., Khan, A. L., Ali, L., Kang, S. M., Kim, Y. H., and Lee, I. J. (2013). Seed germination-influencing bioactive secondary metabolites secreted by the endophyte Cladosporium cladosporioides LWL5. Molecules 18, 15519-15530. doi: 10.3390/molecules181215519

Watson, A. K., and Bailey, K. L. (2013). “Taraxacum officinale F. H. Wigg, Dandelion (Asteraceae)," in Biological Control Programmes in Canada 2001-2012, eds P. G. Mason and D. R. Gillespie. (Oxon: CABI Publishing). 383-391.

Yoshinari, T., Ohmori, K., Schrems, M. G., Pfaltz, A., and Suzuki, K. (2010). Total synthesis and absolute configuration of macrocidin A, a cyclophane tetramic acid natural product. Angew. Chemie Int. Ed. 49, 881-885. doi: 10.1002/anie.200906362

Zhang, Q., Wang, S. Q., Tang, H. Y., Li, X. J., Zhang, L., Xiao, J., et al. (2013). Potential allelopathic indole diketopiperazines produced by the plant endophytic Aspergillus fumigatus using the one strain-many compounds method. J. Agric. Food Chem. 61, 11447-11452. doi: 10.1021/jf403200g

Zhao, H. P., Cui, Z. P., Gu, Y. C., Liu, Y. X., and Wang, Q. M. (2011). The phytotoxicity of natural tetramic acid derivatives. Pest. Manag. Sci. 67, 1059-1061. doi: 10.1002/ps.2210

Conflict of Interest Statement: The authors declare that the research was conducted in the absence of any commercial or financial relationships that could be construed as a potential conflict of interest.

Copyright (c) 2015 Harding and Raizada. This is an open-access article distributed under the terms of the Creative Commons Attribution License (CC BY). The use, distribution or reproduction in other forums is permitted, provided the original author(s) or licensor are credited and that the original publication in this journal is cited, in accordance with accepted academic practice. No use, distribution or reproduction is permitted which does not comply with these terms. 